\title{
PENGARUH KUALITAS LAPORAN KEUANGAN DAN DEBT MATURITY TERHADAP EFISIENSI INVESTASI DENGAN GOOD CORPORATE GOVERNANCE SEBAGAI VARIABEL MODERASI: STUDI PADA PERBANKAN GO PUBLIC DI INDONESIA
}

\author{
Muhammad Dedat Dingkoroci Akasumbawa ${ }^{1}$ \\ Slamet Haryono ${ }^{2}$ \\ ${ }^{1}$ UIN SunanKalijaga Yogyakarta, Indonesia \\ ${ }^{1} 19208010052 @$ student.uin-suka.ac.id \\ ${ }^{2}$ UIN SunanKalijaga Yogyakarta, indonesia \\ ${ }^{2}$ slamet.haryono@uin-suka.ac.id
}

\begin{abstract}
The purpose of this study is to test whether variable quality of financial statements, debt maturity and good corporate governance as moderating the quality of financial statements affect investment efficiency. This study used a panel data model with 40 banking samples going public in Indonesia in 2015-2019. The results showed that the quality of financial statements has a significant positive effect on investment efficiency. Debt maturity shows a positive influence on investment efficiency. However, good corporate governance has no effect in moderating the quality of financial statements with investment efficiency.
\end{abstract}

Keywords :Financial Reporting Quality, Debt Maturity, Investment Efficiency, Good Corporate Governance

\section{PENDAHULUAN}

Penelitian sebelumnya telah menyelidiki mengenai pengaruh laporan keuangan dalam membentuk suatu efisiensi investasi. Pertanyaan mendasar dalam akuntansi adalah sejauh mana laporan keuangan memfasilitasi modal untuk dialokasikan ke investasi yang tepat (Roychowdhury et al, 2019). Pengkajian terdahulu melaporkan bahwa meningginya efisiensi investasi daalm sebuah perusahaan dapat terlihat dari adanya jumlah keuangan dengan kualitas yang sangat tinggi. (Elaoud \& Anis, 2017). Kualitas laporan keuangan mencermintakan manajer dalam suatu perusahaan, kemudian kualitas laporan keuangan yang akurat dapat mengurangi masalah asimetri informasi sehingga peluang investasi dapat diidentifikasi dengan baik yang kemudian meningkatkan efisiensi investasi (Al'Alam \& Amrie (2019).

Penggunaan kualitas informasi akuntansi yang tinggi diharapkan dapat meningkatkan keputusan investasi perusahaan (Houcinel \& Mohamed (2017). Disatu sisi, dengan mengurangi ketidakcocokan berita diantara perusahaan dan investor, hal tersebut akan membantu menarik para investor, menurunkan biaya modal perusahaan, 
dan dengan demikian dapat mengurangi masalah under-investment perusahaan. Disisi lain, kualitas laporan keuangan yang baik akan mengalahkan insentif manajer untuk terlibat dalam investasi yang menghancurkan nilai, hal ini dapat dicapai karena dewan direksi akan menyimpan informasi yang lebih akurat, yang meningkatkan kemampuan mereka dalam memantau kegitan manajer, termasuk dalam membuat keputusan investasi (Hu \& Jean, 2017).

Faktor pertama pada penelitian ini yang dapat mendorong efisiennya suatu investasi adalah kualitas laporan keuangan. Dengan tingginya dari kualitas laporan keuangan memberikan suatu tanggungjawab yang lebih besar bagi seorarng manajer dengan adanya kemungkinan peninjauan yang lebih baik. Selain itu, kualitas laporan keuangan pun dapat memberikan sebuah peningkatan terhadap efisiensi investasi dengan adanya kemungkinan bagi seorang pimpinan perusahaan untuk membuat suatu ketetapan investasi dengan rekognisi proyek yang lebih baik dengan jujur untuk membuat suatu keputusan (Elaouda \& Anis, 2017). Hasil temuan yang didapatkan oleh Roychowdhury et al (2019) dari kajiannya menemukan bahwasanya bobot laporan keuangan yang lebih tinggi dapat mempengaruhi manajer untuk meningkatkan efisiensi investasi.
Faktor selanjutnya yang dapat mendorong efisiensi investasi adalah dengan pendanaan yang tepat yang dapat dilakukan dengan mencari dana utang (debt maturity). Menurut Mazboudi \& Iftekhar (2017), tingkat risiko sistematik di sektor perbankan sebagian besar didorong oleh cara perusahaan membiayai investasi mereka dengan menggunakan lebih banyak utang jangka pendek. Penelitian yang dilakukan oleh Sato \& Chaiporn (2017) menemukan bahwa debt maturity mempunyai pengaruh positif terhadap efisiensi invesatasi perusahaan.

Selain kualitas laporan keuangan dan debt maturity, Good Corporate Governance (GCG) merupakan faktor non-finansial lain yang saat ini banyak dipertimbangkan oleh investor untuk mengevaluasi suatu perusahaan (Sitorus \& Etty, 2019). Adanya GCG yang baik memberikan bukti bahwa kepemilikan manajerial dalam saham mendorong manajer untuk menerapkan pilihan kebijakan yang baik pula sehingga akan lebih banyak investasi yang dating (Azhar, et al, 2019). Penelitian yang dilakukan oleh Sitorus \& Etty (2019) mengemukakan bahwa good corporate governance dapat memperkuat secara positif kualitas laporan keuangan terhadap efisiensi investasi. 
Tabel 1

Total Aset dan Total Ekuitas Bank yang akan di Merger

\begin{tabular}{|l|l|l|}
\hline Perusahaan & $\begin{array}{l}\text { Total asset (Q1 } \\
\mathbf{2 0 2 0})\end{array}$ & $\begin{array}{l}\text { Total Ekuitas } \\
\text { (Q1 2020) }\end{array}$ \\
\hline PT Bank Syariah Mandiri & Rp 114 triliun & Rp 9,61 triliun \\
\hline PT Bank BNI Syariah & Rp 51 triliun & Rp 5,18 triliun \\
\hline PT BRI Syariah Tbk & Rp 42 triliun & Rp 5,16 triliun \\
\hline & Rp 207 triliun & Rp 19,95 triliun \\
\hline
\end{tabular}

Sumber: Otoritas Jasa Keuangan. 2020

Isu mengenai Menteri BUMN

yang akan mengintegrasikan bank syariah dimana ia adalah anak usaha bank pelat merah pada Februari 2021 yang diharapkan mampu menciptakan satu entitas bank syariah baru dengan keseluruhan aset senilai Rp207 triliun (www.bumn.go.id). Terdapat tiga bank umum syariah yang menjadi anak usaha BUMN, diantaranya; PT. Bank Rakyat Indonesia Syariah Tbk (BRIS), PT. Bank BNI Syariah, dan PT. Bank Syariah Mandiri, yang masing-masing total aset dan ekuitasnya sebagaimana tabel 1

Dari ketiga bank Syariah diatas, BRIS menjadi satu dari tiga bank syariah yang tercatat pada bursa efek serta telah menjadi perusahaan publik, sehingga memungkinkan dari BRIS lah yang menjadi induk dari keseluruhan bank syariah. Apabila dari sketsa tersebut dapat benar-benar terjadi, maka bukan hal mustahil apabila jumlah keseluruhan dari kepunyaan khalayak akan terdelusi (bumn.go.id).

Kualitas informasi akuntansi yang baik dapat mempengaruhi efisiensi investasi suatu perusahaan (Elaoud \& Anis, 2017). Oleh karena itu, diduga bahwasanya baiknya dari kualitas laporan keuangan maka memiliki pengaruh yang baik pula terhadapyang baik akan berpengaruh positif terhadap keberhasilan investasi. Roychowdhury et al (2019) mendeklarasikan dari hasil pengkajiannya bahwa bobot laporan keuangan yang lebih tinggi dapat mempengaruhi manajer untuk meningkatkan berhasilnya suatu investasi. Maka diduga bahwa keberhasilan dari sebuah investasi terlihat dari kualitas laporan keuangan.

H1: Kualitas laporan keuangan memiliki dampak positif terhadap efisiensi investasi

Menurut Mazboudi \& Iftekhar (2017), tingkat risiko sistematik di sektor perbankan sebagian besar didorong oleh cara perusahaan membiayai investasi mereka dengan menggunakan lebih banyak utang jangka pendek. Sato \& Chariporn (2017) menemkan dari hasil risetnya bahwasanya debt maturity berpengaruh terhadap investasi perusahaan. Maka diduga bahwa debt maturity mempunyai pengaruh positif bagi efisiensi investasi. 
H2: Debt Maturity mempunyai pengaaruh positif terhadap Efisiensi Investasi

Adanya GCG yang baik memberikan bukti bahwa kepemilikan manajerial dalam saham mendorong manajer untuk menerapkan pilihan kebijakan yang baik pula sehingga akan lebih banyak investasi yang dating (Azhar, et al, 2019). Penelitian yang dilakukan oleh Sitorus \& Etty (2019) mengemukakan bahwa good corporate governance dapat memperkuat secara positif kualitas laporan keuangan terhadap efisiensi investasi. Maka diduga Good Corporate Governance memperkuat pengaruh positif kualitas laporan keuangan terhadap efisiensi investasi.

H3: Good Corporate Governance memberikan kekuatan dampak positif kualitas laporan keuangan terhadap efisiensi investasi

Adanya pengkajian ini memberikan sebuah partisipasi. Diantara kontribusi ataupun partisipasi yang diberikan, diantaranya: pertama, memberikan suatu tambahan yang membahas terkait relasi diantara kualitas laporan keuangan dan debt maturity terhadap efisiensi investasi dengan GCG sebagai variabel moderasi. Kedua, pada pengkajian ini menerapkan pengukuran kualitas dengan revenue accrual yang dikembangkan oleh Mcnichols \& Stubben (2008). Ketiga, penelitian ini secara empiris mengilustrasikan nilai pelaporan jumlah uang, debt maturity, GCG dan efisiensi investasi pada perbankan yang sudah Go Public di Indonesia periode 2015-2019. Terakhir, sebagai penentu keputusan investor dalam memilih investasi yang efisien.

\section{METODE}

$\begin{array}{rrr} & \text { Pendekatan } & \text { yang } \\ \text { dipakai pada pengkajian ini } & \text { ialah }\end{array}$
pendekatan kuantitatif yang sifatnya studi kausal guna memahami terkait pengaruh yang diberikan variable satu terhadap lainnya. (Sekaran \& Bougie, 2017). Kemudian penggunaan sampel pada pengkajian ini diambil dengan penerapan metode purposive sampling, berikut parameternya: 1) Perbankan yang telah go public \&tercatat di BEI; 2) Perbankan yang menerbitkan laporan keuangan tahunan 2015-2019.

Metode pengujiannya dengan memakai regresi data panel dengan total sampel 40 perusahaan perbankan pada tahun 2015-2019. data penel dibutuhkan sebuah uji spesifikasi model yang akurat untuk memilih salah satu cara dari tiga pendekatan (Amyulianthy\& Elsa, 2016: 10). Langkah pertama yaitu memilih antara common effect model vs fixed effect model dengan menggunakan uji Chow. Langkah selanjutnya memilih diantara fixed effect model vs random effect model dengan menggunakan uji 
Hausman. Terakhir memilih common effect model vs random effect model dengan menggunakan uji Langrage Multiplier. Kemudian, guna menerangkan terkait korelasi diantara variabel independent dan variable dependen dengan penggunaan uji hipotesis, yang memuat uji koefisien determinasi (R2), Uji Simultan (Uji F), dan uji parsial (Uji T).

Pada penelitian ini model pengujian hipotesis yaitu untuk

\section{KERANGKA MODEL}

Berdasarkan tujuan dari penelitian ini tentang faktor-faktor yang mempengaruhi efisiensi investasi dapat digambarkan sebagai berikut:

\section{Gambar 1. Kerangka Pemikiran}

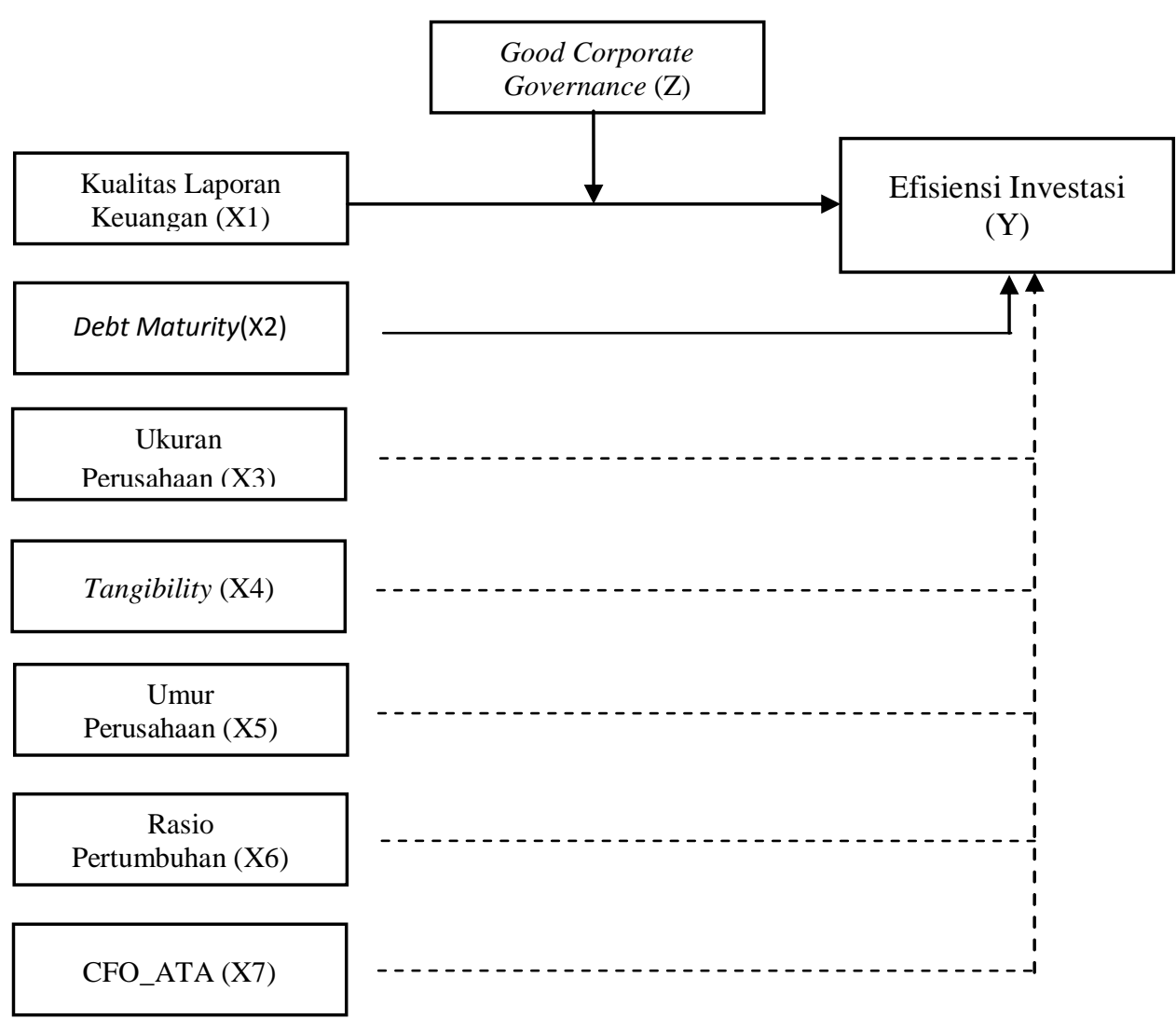
keuangan (X1), dan Debt Maturity (X2) Terhadap Efisiensi Investasi (Y) dengan Good Corporate Governance sebagai variabel moderasi (Z). Di sisi lain pengkajian ini menambahkan pengaruh variabel kontrol yakni Ukuran perusahaan, Tangibilitas, Umur Perusahan, Rasio Pertumbuhan, dan CFO_ATA. 
Variabel dependen yang dimaksud dalam kajian ini ialah efisiensi investasi. Berdasarkan pada Biddle et al (2009), untuk mentaksir tangkat investasi untuk perusahaan i di tahun $t$, maka peneliti memastikan model yang memprediksi tahap investasi berasaskan peluang peningkatam (berdasarkan ukuran dari peningkatan nilai jual). Model untuk menakar dari efisiensi investasi, antara lain :

Investment $_{\mathrm{i}, \mathrm{t}} \quad=\beta 0+\beta 1$ Salesgrowth $_{\mathrm{i}, \mathrm{t}}$ $-1+\varepsilon_{\mathrm{i}, \mathrm{t}}$

Dimana Investment $t_{i t}$ merupakan keseluruhan dari investasi perusahaan $\mathrm{i}$ pada tahun $t$, diartikan sebagai eskalasi bersih asset yang nyata ataupun tidak nyata dan diskalakan dengan lagged total aset. Sedangkan Salesgrowthi,t -1 merupakan tahap alterasi nilai jual sebuah perusahaan i dari t-2 sampai t-1.

Variabel Kualitas Laporan Keuangan terhadap pengkajian ini dapat dilihat dengan penggunaan model yang ditawarkan oleh McNichols \& Stubben (2008) yang memandang bahwasanya pendapatan diskresi sebagai proksi untuk manajemen penghasilan. Untuk mengkomposisikan total accruals menjadi komponen discretionary maka membutuhkan model berikut:

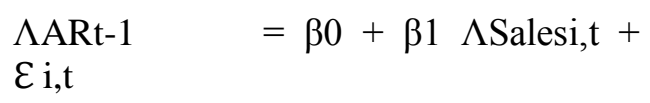

\begin{abstract}
Dimana $\Lambda$ ARt-1
adalah perubahan tahuanan dalam akun piutang untuk perusahaan $\mathrm{i}$ pada tahun $\mathrm{t}$. $\Lambda$ Salesi,t mewakili terhadap perubahan tahunan penghasilan penjualan untuk perusahaan i di tahun t. semua istilah diskalakan dengan total asset yang tertinggal.

Untuk memverifikasi peran debt maturity dalam efisiensi investasi, terhadap kajian ini memakai variabel StDebt kemudian ukurannya menggunakan rasio utang jangka pendek (utang dengan durasi waku belum mencapai setahun) atas keseluruhan dari utangnya (Gomariz \& Juan, 2013).
\end{abstract}

StDebt = Utang jangka pendek / Total Utang

Variabel moderasi dalam pengkajian ini dengan GCG yang merupakan seperangkat aturan yang mengatur relasi diantara yang memegang perushaan, manajer, debitur, pemerintah, pegawai, dan pemangku lainnya yang memiliki keterkaitan atau memiliki kepentingan terkait hak dan kewajiban (Sitorus \& Etty, 2019). Sistem atau metode untuk pengelolaan sebuahh perusahaan dalam pengkajian ini dengan penggunaan proksi komisaris independent dibagi total komisaris yang fungsinya memberikan suaut penilaian terkait kemampuan perusahaan dalam bekerja dengan komprehensif dan 


\section{FAKULTAS EKONOMI DAN BISNIS UNIVERSITAS WIRARAJA - MADURA}

menyeluruh. Untuk mengukur GCG menggunakan rumus berikut:

Independent Commissioner $=$ Dewan Komisaris Independen / Total Dewan Komisaris

Untuk variabel control yang pertama adalah ukuran perusahaan. Proksi pada pengkajian ini berfungsi untuk mencerminkan ukuran perusahaan adalah variabel Lnsales yaitu melihat besaran penjualan perusahaan yang terhitung dengan penggunaan logaritma Natural (Ln) dari keseluruhan dari aset perusahaan.

LnSales $\quad=$ Ln (Total Pendapatan)

Variabel kontrol selanjutnya adalah tangibilitas, karena ukuran perusahaan yang berbeda dapat mempunyai tingkat efisiensi investasi yang berbeda. Variabel tangibilitas digunakan untuk mengontrol efek tangibility yang dihitung menggunakan rasio dari aset tetap perusahaan dibagi total aset.

Tang = Asset Tetap / Total Aset Variabel Umur Perusahaan diukur dari umur perusahaan i pada tahun $\mathrm{t}$ dimana $\mathrm{t}$ adalah tahun yang ketika penelitian dilangsungkan.

Variabel CFO_ATA ialah variabel yang digunakan untuk mengontrol efek arus kas pada investasi perusahaan yang dihitung menggunakan rasio arus kas operasioanal selanjutnya dibagi dengan prata-rata keseluruhan jumlah dari aset perusahaan.
CFO_ATA $=$ Arus Kas Operasi / Average Total Aset

Variabel control terakhir pada penelitian ini adalah rasio pertumbuhan. Rasio pertumbuhan diukur menggunakan kuantitas perusahaan yang berbersikulasi terhadap perusahaan i di tahun t.

Data pada pengkajian ini dengan menerapkan data panel. Uji regresi data panel difungsikan untuk memahami terkait korelasi diantara variabel independen yang memuat diantaranya Kualitas Laporan Keuangan (X1) dan Debt Maturity (X2) terhadap Efisiensi Investasi (Y) dengan Good Corporate Governance (Z) sebagai variabel moderasi.

Terdapat dua model yang dipakai pada pengkajian ini. Model pertama regresi data panel, antara lain :

$$
\begin{aligned}
\text { Efficientit } & =\beta 0+\beta 1 \text { Kualitasit }+ \\
& \beta 2 \text { StDebtit }+\beta 3 \text { Gcgit }+ \\
& \beta 4 \text { LnSalesit }+\beta 5 \text { Tangit }+ \\
& \beta 6 \text { Umurit }+\beta 7 \text { CFO_ATAit } \\
& +\beta \text { R Rtumbuhit }+ \text { eit }
\end{aligned}
$$

Model kedua mengenai pengaruh good corporate governance terhadap hubungan kualitas laporan keuangan dan efisiensi investasi sebagai berikut:

Efficientit $=\beta 0+\beta 1$ Kualitasit + $\beta 2$ Gcgit $+\beta 3$ Kualitasit * Gcgit $+\beta 4$ LnSalesit + $\beta 5$ Tangit $+\beta 6$ Umurit + $\beta 7$ CFO ATAit $\beta 8$ Rtumbuhit + eit 
Dimana Efficient $=$ Efisiensi Investasi, $\mathrm{B}=$ koefisien, Kualitasit = Kualitas Laporan Keuangan perusahaan i pada tahun t, Gcg = Good Corporate Governance i pada tahun $\mathrm{t}$, StDebtit = Debt Maturity perusahaan i pada tahun t, Kualitasit $*$ Gcgit $=$ Moderasi kualitas laporan keuangan dengan GCG perusahaan i pada tahun $\mathrm{t}$, LnSalesit $=$ Ukuran perusahaan i pada tahun $\mathrm{t}$ dilihat dari pendapatan, Tangit $=$ Tangibilitas perusahaan $\mathrm{i}$ pada tahun $\mathrm{t}$, Umurit $=$ Umur perusahaan $\mathrm{i}$ pada tahun $\mathrm{t}$, CFO_ATAit $=$ Efek arus kas perusahaan i pada tahun $t$, Rtumbuhit = Rasio pertumbuhan perusahaan i pada tahun $t$, $\mathrm{e}=$ error term.

\section{HASIL PENELITIAN}

Table 3 menunjukkan statistic deskriptif mengenai variabel yang digunakan dalam penelitian. Dari tabel dibawah ini dapat dipahami bahwasanya nilai rata-rata efisiensi investasi pada perbankan go public di Indonesia adalah -12.88 yang artinya efisiensi investasi yang ada belum dapat dikatakan baik karena jauh di bawah titik optimum yaitu 0.00. Rata-rata kualitas laporan keuangan berada diangka 192.64 yang artinya angka tersebut menunjukkan kualitas laporan keuangan yang baik. Debt maturity mempunyai nilai rata-rata sebesar 0.04 bermakna perusahaan perbankan menggunakan utang jangka pendeknya untuk mengurangi risiko sebesar $4 \%$. Kemudian, good corporate governance mempunyai rata nilai yakni senilai0.56 yang artinya perusahaan perbankan di Indonesia sudah melakukan manajerial yang baik.

Rata-rata LnSales (Ukuran perusahaan dilihat dari pendapatan) sebesar 2.54 triliun yang dapat dikatakan sudah cukup baik. Rata-rata Tangibilitas sebesar 0.025 yang artinya masih kecil yaitu $2 \%$. Umur perusahaan mempunyai nilai rata-rata sebesar 40.87 tahun yang artinya sebagian besar perusahaan perbankan di Indonesia sudah pada tahap dewasa. CFO_ATA memiliki nilai rata-rata 0.0015 , artinya besar arus kas dari aktivitas operasi masih kecil. Terakhir rata-rata rasio pertumbuhan perusahaan sebesar 1.4 miliar lembar saham yang beredar.

Dalam menganalisis data panel, diperlukan uji spesifikasi model dengan penggunaan uji Chow, uji Hausman, dan Uji Langrage Multiplier. Berdasarkan pengujian pemilihan model yang dipilih ialah Common Effect, tetapi ketika pengujian uji asumsi klasik, model terkenal masalah heteroskedastisitas. Maka model paling cocok yang diterapkan yakni model Generalized Least Squared (GLS).

Tabel 4 menyajikan hasil pegujian regresi mengenai pengaruh variabel independent terhadap variabel dependen (Uji F). Variabel dependen 
diartikan efisiensi investasi dapat diterangkan oleh variabel independent yang terdiri dari kualitas laporan keuangan, debt maturity dan good corporate governance. Serta variabel control yang terdiri dari LnSales, Tang, Umur perusahaan, CFO_ATA, dan rasio pertumbuhan. Hasil menunjukkan bukti pengaruh yang kuat bahwa variabel independent, variabel moderasi, dan variabel kontrol mempengaruh variabel dependen sebesar $86.5 \%$ dan $13.5 \%$ yang terpengaruh oleh variabel lain diluar pengkajian ini.

Hasil uji t diatas menggambarkan bahwasanya variabel kualitas pada laporan keuangan memiliki pengaruh positif signifikan terhadap efisiensi investasi dengan nilai sig $<0.05$ yaitu 0.0000 dengan Coefficient sebesar 0.035009. Variabel debt maturity juga berpengaruh positif signifikan terhadap efisiensi investasi dengan nilai sig $<0.05$ yaitu 0.0007 dengan Coefficient sebesar 3.57E+16. Variabel Good Corporate Governance tidak berpengaruh terhadap efisiensi investasi dengan nilai sig $>0.05$

$$
\text { Yakni 0.3499. Variabel }
$$

moderasi juga tidak memiliki pengaruh pada efisiensi investasi dengan nilai sig $>0.05$ yaitu 0.6064. Untuk variabel control, hanya variabel LnSales dan CFO_ATA yang berpengaruh positif signifikan terhadap efisiensi investasi dengan nilai sig $<0.05$ yakni 0.000 . sedangkan variabel Tang, Umur, dan Rasio Pertumbuhan tidak berpengaruh terhadap efisiensi investasi dengan nilai sig masing-masing 0.2044, 0.4598, dan 0.4647 .

Tabel 3.

Statistik Deskriptif

\begin{tabular}{|l|l|l|l|l|l|}
\hline Variabel & N & Mean & Minimum & Maximum & Std. Deviasi \\
\hline Efficient & 200 & -12.88000 & $-1.70 \mathrm{E}+17$ & $4.12 \mathrm{E}+17$ & $8.60 \mathrm{E}+16$ \\
\hline Kualitas & 200 & 192.6400 & $-4.92 \mathrm{E}+18$ & $8.14 \mathrm{E}+18$ & $1.85 \mathrm{E}+18$ \\
\hline StDebt & 200 & 0.042086 & 0.001532 & 1.034700 & 0.105068 \\
\hline Gcg & 200 & 0.569647 & 0.333333 & 1.000000 & 0.112840 \\
\hline Kualitas*Gcg & 200 & $-9.64 \mathrm{E}+15$ & $-2.46 \mathrm{E}+18$ & $4.07 \mathrm{E}+18$ & $1.01 \mathrm{E}+18$ \\
\hline LnSales & 200 & $2.54 \mathrm{E}+12$ & $-6.48 \mathrm{E}+12$ & $3.44 \mathrm{E}+13$ & $6.74 \mathrm{E}+12$ \\
\hline Tang & 200 & 0.025350 & 0.001498 & 0.112191 & 0.021986 \\
\hline Umur & 200 & 40.87500 & 1.000000 & 78.00000 & 18.29434 \\
\hline CFO_ATA & 200 & 0.001511 & -0.231705 & 0.150382 & 0.064641 \\
\hline Rtumbuh & 200 & $1.40 \mathrm{E}+18$ & $1.04 \mathrm{E}+09$ & $1.00 \mathrm{E}+20$ & $1.14 \mathrm{E}+19$ \\
\hline
\end{tabular}

\section{Sumber: Diolah dengan Eviews 10}


Tabel 4.

Hasil Pengujian Regresi

\begin{tabular}{|l|l|l|l|}
\hline Variable & Coefficient & t-Statistic & Probability \\
\hline C & $-8.32 \mathrm{E}+15$ & -3.512498 & 0.0006 \\
\hline Kualitas & 0.035009 & 25.74937 & 0.0000 \\
\hline StDebt & $3.57 \mathrm{E}+16$ & 3.454873 & 0.0007 \\
\hline Gcg & $-3.03 \mathrm{E}+15$ & -0.937066 & 0.3499 \\
\hline Kualitas*Gcg & 0.003197 & 0.516104 & 0.6064 \\
\hline LnSales & 2709.743 & 4.445614 & 0.0000 \\
\hline Tang & $-1.79 \mathrm{E}+16$ & -1.273558 & 0.2044 \\
\hline Umur & $2.34 \mathrm{E}+13$ & 0.740665 & 0.4598 \\
\hline CFO_ATA & $3.52 \mathrm{E}+16$ & 6.090686 & 0.0000 \\
\hline Rtumbuh & $3.14 \mathrm{E}-05$ & 0.732569 & 0.4647 \\
\hline F-Statistik & $\mathbf{1 6 0 . 2 7 1 5}$ & \\
\hline Adjusted R-Square & $\mathbf{0 . 8 6 4 9 1 7}(\mathbf{8 6 . 5 \% )}$ & \\
\hline
\end{tabular}

Sumber: Diolah dengan Eviews 10

Pengaruh Kualitas Laporan

Keuangan terhadap Efisiensi Investasi

Hipotesis pertama kajian ini

ialah kualitas laporan keuangan berdampak positif terhadap efisiensi investasi. Berlandaskan pada hasil dari uji hipotesis diatas, hipotesis pertama diterima. Kualitas laporan keuangan yang baik memberikan suatu tanggungjawab lebih dari seorang manajer dalam melakukan pemantauan yang lebih baik. Selain itu, bertumbuhnya efisiensi investasi dapat terlihat dari kualitas laporan keuangan sehingga terdapat kemungkinan dari manajer untuk memberi suatu ketetapan investasi yang lebih baik berdasar pada identifikasi proyek yang lebih baik dengan jujur untuk membuat suatu keputusan (Elaouda \& Anis, 2017). Kualitas informasi akuntansi yang baik dapat mempengaruhi efisiensi investasi suatu perusahaan (Elaoud \& Anis, 2017).

Pengkajian ini memiliki keselarasan dengan kajian dari Elaoud $\&$ Anis (2017) yang meneliti hubungan kualitas laporan keuangan dan efisiensi investasi menggunakan metode OLS dengan observasi 85 perusahaan pada tahun 2007-2013. Hasil temuan lainnya yang memiliki kesamaan dengan penulis ialah pengkajian yang ditunjukkan (Alam \& Amrie, 2019; Houcinel \& Mohamed, 2017; Roychowdhury et al, 2019). Meningkatnya kapasitas seorang pemilik perusaham dalam memberikan suatu pantauan kepada seorang manajer serta meminimalisir dari berlebihnya investasi dapat ditinjau dari tingginya Kualitas laporan keuangan. 


\section{FAKULTAS EKONOMI DAN BISNIS UNIVERSITAS WIRARAJA - MADURA}

Pengaruh Debt Maturity terhadap Efisiensi Investasi

Hipotesis kedua pada pengkajian ini mengenai debt maturity dapat mempengaruhi efisiensi investasi secara positif dan hipotesis diterima. Menurut Mazboudi \& Iftekhar (2017), tingkat risiko sistematik di sektor perbankan sebagian besar didorong oleh cara perusahaan membiayai investasi mereka dengan menggunakan lebih banyak utang jangka pendek. Debt maturity dapat mengurangi masalah over-investment dan under-investment yang mana dapat mempengaruhi efisiennya suatu investasi. Menurunnya asimetri informasi dapat disebabkan oleh penggunaan utang jangka pendek yang lebih besar. Untuk itu debt maturity dapat digunakan untuk mengurangi munculnya masalah underinvestment yang kemudian menghasilkan investasi yang efisien (Gomeris et al, 2014).

$$
\text { Pengkajian ini memiliki }
$$
keselarasan dengann kajian dari Sato \& Chairporn (2017) yang meneliti dampak debt maturity terhadap efisiensi investasi yang menggunakan data panel tahun 1991-2013 dengan studi kasus pada perusahaan public di US. Penelitian tersebut juga seiring dengan Jiang et al (2019) yang mengungkapkan bahwasanya restrukturisasi utang dapat mempengaruhi efisiensi investasi.
Good Corporate Governance sebagai pemoderasi pengaruh positif Kualitas Laporan Keuangan terhadap Efisiensi Investasi

Hipotesis ketiga pada karya ini ialah good corporate governance dapat memperkuat dampak positif kualitas laporan keuangan terhadap efisiensi investasi. Hasil dari kajiannya menerangkan bahwa hipotesis gagal diterima. Adanya good corporate governance belum tentu dapat mencerminkan kepemilikan manajerial yang baik dalam perusahaan, sehingga hal tersebut tidak menjamin efisiennya suatu investasi.

Inefisiensi investasi dapat terjadi karena pemilik perusahaan pengendali memiliki hal yang lebih besar untuk melakukan pengendalian perusahaan dan hak-hak pemegang saham minoritas sebagai akibat dari konsentrasi kepemilikan tinggi (Anelia \& Andrian, 2020). Hasil menunjukkan bahwa GCG dalam penelitian ini tidak signfikan dalam memperkuat hubungan kualitas laporan keuangan dengan efisiensi investasi. hal ini dapat terjadi karena setengah dari perusahaan yang menjadi objek penelitian memiliki persentase rata-rata lebih dari 50\%, artinya dapat menyebabkan penurunan kekuatan informasi. Sehingga, hal tersebut dapat menjadi alasan mengapa good corporate 
governance tidak memiliki efek jika dikaitkan dengan efisiensi investasi.

$$
\text { Pengkajian yang penyusun }
$$
lakukan tidak memiliki keselarasan dengan kajian dari Sitorus \& Etty (2019) yang menemukan bahwasanya GCG mempunyai pengaruh terhadap efisiensi investasi sebagai pemoderasi kualitas laporan keuangan dengan efisiensi investasi. Namun, penelitian ini sejajar dengan tulisan yang datang dari Anelia \& Andrian (2020) yang memproklamirkan bahwasanya GCG yang diestimasikan dengan ownership consentrate tidak memiliki pengaruh terhadap efisiensi investasi. Pun demikian dengan kajian oleh (Suman \& Shveta, 2020; Ullah et al, 2020) menghasilkan bahwasanya GCG tidak berpengaruh dalam meningkatkan efisiensi investasi.

\section{KESIMPULAN DAN SARAN}

Penelitian ini berkontribusi pada penambahan literatur mengenai efisiensi investasi. Pentingnya laporan keuangan dapat menjadikan referensi bagi para investor dalam memilih investasi yang efisien dan juga bagaiman manajer dalam mengelola modal investor (Roychowdhury et al, 2019). Oleh karenanya , tiitk fokus kajian ini penelitian ini berfokus pada faktorfaktor yang mendasari hal apa saja yang dapat meningkatkan efisiensi investasi. Sedangkan, untuk tujuan dari pengkajian ini yakni untuk menentukan apakah kualitas laporan keuangan, debt maturity dan good corporate governance sebagai pemoderasi kualitas laporan keuangan dengan efisiensi investasi dapat mempengaruhi efisiensi investasi. Selain itu, peneliti juga menambahkan variabel control dalam menentukan efisiensi investasi. Untuk itu, peneliti menggunakan 40 sampel perusahaan perbankan go public di Indonesia dari tahun 2015-2019.

Temuan kami menyatakan bahwasnaya kualitas laporan keuangan mempunyai pengaruh positif signifikan terhadap efisiensi investasi. Baiknya kualitas laporan keuangan mampu memberikan peningkatan terhadap efisiensi investasi serta mendatangkan banyak investor. Debt maturity juga berpengaruh positif signifikan terhadap efisiensi investasi. Perusahaan . Menurunnya asimetri informasi dapat disebabkan oleh penggunaan utang jangka pendek yang lebih besar yang kemudian dapat meningkatkan efisiensi investasi. Sedangkan good corporate governance tidak mempunyai pengaruh dalam memoderasi kualitas laporan keuangan dengan efisiensi investasi. Maka, good corporate governance bukan variabel yang dapat memperkuat hubungan positif antara kualitas laporan keuangan dengan efisiensi investasi. Dari variabel control, hanya ukuran 
perusahaan dan arus kas operasi yang memiliki pengaruh positif signifikan terhadap efisiensi investasi.

Penelitian ini memiliki implikasi penting bagi literatur efisiensi investasi. Ini menunjukkan pentingnya mempertimbangkan kualitas laporan keuangan dan pemakaian utang jangka pendek dalam mengelola suatu perusahaan. Serta perlu mempertimbangkan ukuran perusahaan dan arus kas dari operasi yang dilakukan oleh perusahaan. Relevan dengan masa saat ini bahwa peraturan tentang perbankan telah banyak mengalami perkembangan. Untuk itu perusahaan harus hati-hati dalam mengatur keuangan sehingga menimbulkan investasi yang efisien.

Hasil empiris dari penelitian ini dapat memberikan peluang bagi penelitian masa depan. Investigasi serupa dapat dilakukan pada sampel yang lebih jauh dan besar. Kemudian studi selanjutnya dapat menggunakan model terbaru atau menggunakan data times series sehingga dapat menguji hubungan jangka Panjang atau pendek. Variabel yang digunakan padterhadap pengkajian ini terbatas, untuk itu penelitian selanjutnya perlu menambah faktor lain seperti spesialisasi editor, teknologi, asimetri informasi, risiko sistematik (Elaoud \& Anis, 2017; Hu \& Jean, 2017; Sato \& Chairporn, 2017) yang dapat mempengaruh efisiensi investasi. Terakhir, penelitian ini dapat diperluas dengan menggunakan sampel lintas negara, karena system pemerintahan dibeberapa negara sangat bervariasi. Akibatnya memungkinkan dapat memberikan hasil yang variatif.

\section{DAFTAR PUSTAKA}

Alam, Muhammad Panji Anugerah \& Amrie Firmansyah. (2019). The effect of financial reporting quality, debt maturity, political connection, and corporate gevernance on investment efficiency: Evidence from indonesia. International Journal of Innovation, Creativity and Chage: www.ijicc.net Volume 7, Issue 6, 2019

Amyulianthy, Rafrini\& Elsa K. Ritonga. (2016). The Effect of Economic Value Added and Earning Per Share To Stock Return (Panel Data Approachment). International Journal of Business and Management Invention. Vol. 5 Issue 2, Febuari 2016, PP-0815, ISSN: 2319-8028.

Anelia, Faviola Lady \& Andrian Budi Prasetyo. (2020). The effect of ownership structure on investment efficiency (Case study in non financial firms listed on Indonesia Stock Exchange in 2015-2017). Accounting research journal of Sutaatmaja (ACCRUALS), Vol. 04, No. 01, 2020, ISSN 26150409.

Aulia, Darlin. Sylvia Veronica Siregar. (2018). Financial Reporting Quality, Debt Maturity, and Chief Executive Officer Career Concerns on Investment Efficiency. Brazilian Administration Review (BAR), Vol. 15, No. 2, art. 3, e170120, 2018. 
Azhar, Abdullah Bin. Nasir Abbas. Abdul Waheed. Qaisar Ali Malik. (2019). The Impact of Ownership Structure and Corporate Governance on Investment Efficiency: An Empirical Study From Pakistan Stock Exchange (PSX). Pakistan Administrative Review, 3(2), 84-98.

Biddle, Gary C. Gilles Hilary \& Rodrigo S. Verdi. (2009). How does financial reporting quality relate to investment efficiency?. Elsevier: Journal of Accounting and Economics. Doi: 10.1016/j.jacceco.2009.09.001.

Bushman, R \& A. Smith. (2001). Financial Accounting Information and Corporate Governance. Journal of Accounting and Economics, 32, 237-3.

Elaoud, Assawer \& Anis Jarboui. (2017). Auditor specialization, accounting information quality, and investment efficiency. Elsevier: Research in International Business and Finance.http://dx.doi.org/10.1016/ j.ribaf.2017.07.006

Gomariz, M Fuensanta Cutillas. Juan Pedro Sanchez Ballesta. (2013). Financial Reporting Quality, Debt Maturity and Investment Efficiency. Elsevier, Journal of Banking \& Finance, http://dx.doi.org/10.1016/j.jbankfi n.2013.07.013

Hu, Yingyi \& Jean-Luc Prigent. (2017). Information asymmetry, Cluster trading, and Market efficiency: Evidence from the chinese stock market. Elsevier: Economic Modeling,

https://doi.org/10.1016/j.econmod .2018.04.001
Houcinel, Asma \& Mohamed Chakib Kolsi. (2017). The effect of financial reporting quality on corporate investment efficiency: Evidence from the Tunisian Stock Market. Research in International Business and Finance: http://dx.doi.org/doi:10.1016/j.rib af.2017.07.066

Jiang, Jinglu, Bo Liu, Jingjiang Yang. (2019). The impact of debt restructuring on firm investment: Evidence from China. Elsevier: Economic Modeling, doi: https://doi.org/10.1016/j.econmod .2019.05.019

Jensen \& Meckling. (1976). Theory of firm: Managerial behaviour, Agency Costs and Ownership Structure. Journal of Financial Economics, Oct, 3(4), 305-360.

Kasznic R. (1999). On the association between voluntary disclosure and earnings management. Journal of Accounting Research, 37 (1), 5781.

Krismiaji. Djaja Perdana. (2018). Accounting Information Quality and Capital Investment Choice in the Governance Perspective - an Indonesian Evidence. International Journal of Business Management and Economic Research (IJBMER), Vol. 9 (2), 2018, 1236-1243

Mazboudi, Mohamad \& Iftekhar Hasan. (2017). Secrecy, Information shocks, and corporate investment: Evidence form European Union Countries. Journal of International Financial Markets, Institutions \& Money: https://doi.org/10.1016/j.intfin.20 17.11.002.

Mcnichols, M. F \& Stubben S. R. (2008). Does Earnings management affect firms investment decisions? American Accounting Association, 83(6), 1571-1603. 
Myers, S \& Majluf N. (1984). Corporate financing and investment decisions when firms have information that investors do not have. Journal of Financial Economics, 13, 187-221.

Permatasari, Yani \& Ana Vebri Rahmadini Nengtyas. (2020). The Effect of Financial reporting and debt maturity quality of investment efficiency with litigation risk as moderated variables. International Journal of Innovation, Creativity and Change, Vol. 10, Issue 12, 2020.

Quynh, Trang Phan. (2018). Corporate Debt and Investment with Financial Constrainsts: Vietnamese Listed Firms. Research in International Business and Finance, https://doi.org/10.1016/j.ribaf.201 8.03.004.

Roychowdhury, Sugata. Nemit Shroff \& Rodrigo S. Verdi. (2019). The effect of financial reporting and disclosure on corporate investment: A Review. Elsevier: Journal of Accounting and Economics.

https://doi.org/10.1016/j.jacceco.2 019.101246

Sato, Meg Adachi. Chairporn Vithessonthi. (2017). Bank systematic risk and corporate investment: Evidence from the US. Internatioanl Review of Financial Analysis, doi: 10.1016/j.irfa.2017.02.008.
Sitorus, Riris Rotua. Etty Murwaningsari. (2019). Do Quality of financial reporting and tax inventives effect on corporate investment efficiency with good corporate governance as moderating variables?. Journal of Accounting, Bussiness and Finance Research. Vol. 6, No. 1, ISSN: 2521-3830.

Sugiyono. (2013). Metode Penelitian Kuantitatif, Kualitatif, dan Kombinasi (Mixed Method). Alfabeta: Bandung.

Suman, Samridhi \& Shveta Singh. (2020). Corporate governance mechanisms and corporate investments: Evidence from India. International Journal of Productivity and Performance Management, Emerald, 17410401.

Ullah, Irfan. Muhammad Ansar Majeed. Hong-Xing Fang. (2020). Female CEOs and Corporate Investment Efficiency: Evidence From China. Borsa Intanbul Review, PII: S2214-8450(20)30060-0.

Yoshikawa H. (1980). On the " $q$ " theory of investment. American Economic Review, 70, 739-743.

Van Besst, Ferdy. G. Braam \& S. Boelens. (2009). Quality of Financial reporting: Measuring qualitative characteristics. NiCE Working Paper 09-108. Radboud University Nijmegen. 